\title{
The Level of Lighting and Ventilation on the Incidence Rate of Pulmonary TB
}

\author{
Isma Yuniar ${ }^{1}$, Siti Rusmindarti ${ }^{2}$, Sarwono $^{3}$ \\ \{ismayuniar@gmail.com $\left.{ }^{1}\right\}$ \\ Muhammadiyah of Health Sciences College of Gombong, Central Java, Indonesia ${ }^{1,2,3}$
}

\begin{abstract}
Pulmonary TB was the highest infectious disease in the world. TB eradication is the main focus of the government. Many factors can be affected the occurrence of pulmonary TB one of them is the condition of the home including lighting and ventilation. The purpose of this study was to determine the relationship between the level of lighting and ventilation on the incidence rate of pulmonary TB. The type of this research was correlational analytic with a case-control approach. Case samples are 40 patients with pulmonary TB, and control samples are 40 respondents who have not been exposed to pulmonary TB. The results of this study indicate there is a relationship between lighting at home with the incidence of pulmonary tuberculosis, with the value of the statistical test results $p=0.036$. While the measurement of the relationship of ventilation with the occurrence of pulmonary TB mentioned no relationship with the value of the statistical test results $\mathrm{p}=0.309$. The conclusion is that lighting factors are a risk factor for TB incidents, so the community needs to arrange their homes to get adequate lighting.
\end{abstract}

Keywords: Level of lighting, Ventilation, Pulmonary TB, Incidence rate

\section{Introduction}

Tuberculosis is a disease of global concern; various control efforts have been made to reduce the incidence and death caused by tuberculosis. In Indonesia tuberculosis became the second rank with a number of cases is $10 \%$ of all sufferers in the world. While the new cases of tuberculosis in the world on the age under 15 years reached 1 million with a total of 140,000 deaths every year [18].

In 2014 at Central Java Province, the child cases proportion of tuberculosis had an incidence of $6.63 \%$, this shows that the transmission of pulmonary tuberculosis to children was quite large. Acid Resistant Bacteria pulmonary tuberculosis positive adults infecting as many as 1,386 children and are successfully found and treated [3]. Environmental health includes all physical, social and biological factors from outside of the human body and all the factors that can influence human behavior. The conditions and controls of environmental health have the potential to influence health [17].

The agent and the environment, both of them are important factors for the transmission of Mycobacterium Tuberculosis from the sufferer to other people around the patients. Agents in the air can occur because the patient has spitting behavior in any place while the patient's droplet still contains Mycobacterium Tuberculosis. Environmental factors of the patient also increase the risk of transmission of Mycobacterium Tuberculosis such as a poor housing environment so 
that it can increase the transmission of Mycobacterium Tuberculosis from the sufferer to their family members who are in the same house [7].

A home environment that can influence the high incidence of pulmonary tuberculosis is an unhealthy home environment such as less of good ventilation facilities, poor lighting in the room, residential solidity in the house and building materials in the house. In addition to the home environment that influences tuberculosis, physical environment, biological environment and social environment will also be detrimental to health and can affect tuberculosis and ultimately affect the high incidence of tuberculosis [10].

Mycobacterium tuberculosis likes humid places and it will grow in 31 - 370 optimally. One of the problems in lung tuberculosis cases is there are many people who still cannot have and provide healthy environment. Based on the data from tuberculosis analists, Sari et al [16], they stated that the number of houses with PHBS in Kebumen was increasing in past three years. However, if we take a look at in more detailed, it is still not equally implemented. In addition, the percentage of hospital in Kebumen in 2011 is only $65.76 \%$.

This research is supported by Permatasari [14] which states that the factors can influence the success of pulmonary TB are: a) facilities of factors which include the availability of adequate and continuous medication, education of health cares, and administration of adequate drugs, b) patient factors which include knowledge, awareness and determination to recover, and personal hygiene, c) family and community environmental factors.

According to the Tuberculosis Situation Analysis in Kebumen [16], the trend of TB incidence in Kebumen Regency is increasing, and one of the causes is environmental factors. A healthy environment can be categorized if it has carried out community life behavior, especially the family itself that behave in a clean and healthy life. Based on data that has been obtaining that Kebumen regency experienced a quantitative increase in clean and healthy leaving behavior. However, in terms of quality, there are still residential buildings do not support the health requirements of homes that have healthy latrines, clean water, landfills, good ventilation, suitable residential densities and impermeable housing floors [10]. Based on this description above, the researchers formulated the problem regarding the relationship between lighting, ventilation against TB cases.

\section{Method}

This research used is a correlational analytic type with a case-control approach. Case population in this study were all patients with pulmonary tuberculosis who were on treatment or had been infecting with positive smear pulmonary tuberculosis in the working area of Health Centre care of Sempor 1 working area, as many as 40 respondents. The control population in this study were all people who were not patients with positive smear pulmonary tuberculosis or who had not been infected with pulmonary tuberculosis in the working area of Health Centre care of Sempor 1 and who did not live with pulmonary tuberculosis sufferers. The operational definitions in this study are 1) ventilation, which is the comparison between the area of the solidity wall of the house that functions to get in and out of the air with the floor area of the house, 2) the lighting in the bedroom of the patient with pulmonary tuberculosis, 3) Respondents who have been declared infected Acid Resistant Bacteria +tuberculosis by the Health Centre care of Sempor 1. The Data collection techniques in this study used direct measurement using a meter and Lux meter. 1) Meter, to measure the ratio of ventilation with a floor area of a house and measure the occupancy solidity of the room, 2) Lux meter, to measure room lighting. 
Bivariate analysis was performed to determine the relationship between the independent variables and the dependent variable. In this study data analysis was carried out to determine the relationship of lighting with ventilation to the incidence of pulmonary tuberculosis (TB).

\section{Results and Discussion}

\subsection{Relationship Between Ventilation and Pulmonary Tuberculosis in The Working Area of Health Centre of Sempor 1}

Table 1 Correlation analysis of the relationship of home ventilation with the incidence of pulmonary tuberculosis in the working area of Health Centre of Sempor 1.

Table 1. Correlation analysis of the relationship of home ventilation with the incidence of pulmonary tuberculosis in the working area of Health Centre of Sempor 1

\begin{tabular}{|c|c|c|c|c|c|c|c|}
\hline \multirow{3}{*}{ No } & \multirow{3}{*}{ Ventilation } & \multicolumn{5}{|c|}{$\begin{array}{c}\text { TB cases } \\
\end{array}$} & \multirow{3}{*}{ OR } \\
\hline & & \multicolumn{2}{|c|}{ Patients with pulmonary TB } & \multicolumn{2}{|c|}{ No suffer pulmonary TB } & \multirow{2}{*}{$p$-value } & \\
\hline & & $\mathbf{F}$ & $\%$ & $\mathbf{F}$ & $\%$ & & \\
\hline 1. & Qualified & 8 & 10 & 13 & 16,2 & & \\
\hline 2. & Not eligible & 32 & 40 & 27 & 33,8 & 0,204 & 0,519 \\
\hline
\end{tabular}

Based on table 1, it is known that the majority of respondents who suffer from pulmonary tuberculosis are followed by the condition of ventilation of houses that do not meet the requirements of 32 respondents $(40.0 \%)$, and respondents who are not sufferers of pulmonary tuberculosis the majority of ventilation does not qualify the requirements of 27 respondents $(33.8 \%)$. The results of statistical calculations show the $\mathrm{p}$-value $=0.204$ where $\alpha=0.05$ so that the $\mathrm{p}$-value $>\alpha$ which means there is no relationship between house ventilation and the incidence of pulmonary tuberculosis.

Natural ventilation is measured by comparing the ventilation area with the floor area. Fulfilling the requirement or not a natural ventilation of the respondent's house can be caused by several things such as the area of the house that is not comparable with the area of ventilation and windows or ventilation made of glass that cannot be opened. Some of the respondents' houses have ventilation that can be opened and closed, but due to reasons for safety security of house, respondents choose not to open ventilation even in the afternoon.

Lyzigos [9] stated that closed windows causes' poor house, ventilation thereby increasing the risk of TB transmission. Ventilation is a condition of a house that has sufficient air circulation in and out with a ventilation area of at least $10 \%$ of the floor area. Poor ventilation can affect the incidence of TB. A room with a ventilation area that does not qualify $(<10 \%$ floor area) causes high humidity and temperature in the room due to less of air exchanges from outside the house, giving $10 \mathrm{~TB}$ bacteria the chance to survive inside the room due to the nature of TB bacteria who can survive in a dark and damp room

The results of this study are supported by Riswanto's research [15], it shows that poor ventilation is more at risk of tuberculosis exposure. Important ventilation is in the house as a place for air circulation. Indoor air quality is affected by the presence or absence of ventilation which of course must meet the requirements of $10 \%$ wider than the floor. According to research by Fatimah [4], ventilation is also a risk factor for tuberculosis. The results of statistical calculations show the $\mathrm{p}$-value $=0.204$ where $\alpha=0.05$ so that the $p$-value $>\alpha$ which means there is no relationship between house ventilation and the incidence of pulmonary tuberculosis. 
The results of this study are in line with the results of the study of Dewi, et al (2016) which states that there is no significant relationship between the area of ventilation of the house with the incidence of pulmonary TB ( $\mathrm{p}$-value $=0.226, \mathrm{OR}=2.212$ and 95\% CI $=0.718-6.817$ ). Although the results of this study are not significant, the presence of ventilation can be a factor influencing the transmission of pulmonary $\mathrm{TB}$, houses with less ventilation will affect the incidence of pulmonary tuberculosis.

Home ventilation functions to remove polluted air (bacteria, $\mathrm{CO}_{2}$ ) in the house and replace it with fresh and clean air or for air circulation in which ultraviolet light enters. This is in line by Fatimah [4] research which states that the presence of ventilation has a risk of 5.17 times the transmission of TB (OR 5.17, CI $=95 \% ; 1.55-17.9)$. In this study ventilation is a risk factor associated with the incidence of pulmonary tuberculosis. Natural ventilation that fulfils of qualify facilitates the entry of ultraviolet (UV) light into the house. UV rays can kill pathogenic bacteria including TB bacteria because of the nature of TB bacteria that are unable to survive if exposed directly. Natural ventilation, such as open windows, can be sufficient to provide adequate ventilation, even if mechanical ventilation is not available. Any ventilation system should be monitored and maintained regularly. If ventilation is not sufficient, HEPA filter or UVGI can be used as complementary measures. Personal protection provides additional benefit in TB prevention. Wearers should select certificated respirators. Besides, the implementation of both fittest and fit check can improve the protective effect by increasing the likelihood of achieving an adequate fit [15].

Recognition of basic principles of TB infection control will be beneficial for both HCWs and patients to be protected from infection risks. There is a high estimated risk of TB transmission in traditional homes of infectious TB patients in rural South Africa. Improving natural ventilation may decrease household TB transmission risk and, combined with other strategies, may enhance TB control efforts.

There is little evidence that ventilation directly reduces the risk of disease transmission, but many studies suggest that insufficient ventilation increases disease transmission. A number of studies have looked at the possible transmission routes of diseases, but few have looked at the direct impact of ventilation on disease transmission. Detection of pathogens in room air and buildings may suggest a possible, indirect association between ventilation and disease transmission. However, other aspects (e.g. necessary infecting dose, the susceptibility of the host, infectivity of the pathogen, other environmental factors) are important for determining the ability of a pathogen to be transmitted. Therefore, data on the presence of pathogens in the air does not provide the full evidence for disease transmission and should be used in conjunction with other data (e.g. epidemiological data) [4].

Air volume is very important to be considered and to be used to make sure the air sufficiency in a room because if the room area is sufficient but the volume is not sufficient, the air circulation will be not smooth. House with minimal ventilation will supply insufficient fresh air. People need to have more ventilation in their houses. They also have to consider the volume of the room, so that they can provide the sufficient air for the people who live and stay in their houses. Based on the analysis about the orientation variable of the sunlight that comes inside the houses shows that there is a meaningful correlation between the sunlight that comes inside the houses and lung tuberculosis cases [5]. 


\subsection{The Relationship Between Room Lighting and Pulmonary Tuberculosis in The Health Center of Sempor 1 Working Area}

Table 2 The results of the Chi-square correlation analysis of the relationship of room lighting with the cases of pulmonary tuberculosis in the working area of Health Center of Sempor 1.

Table 2. The results of the Chi-square correlation analysis of the relationship of room lighting with the cases of pulmonary tuberculosis in the working area of Health Center of Sempor 1

\begin{tabular}{|c|c|c|c|c|c|c|}
\hline \multirow{3}{*}{ No } & \multirow{3}{*}{ Lighting } & \multicolumn{5}{|c|}{ TB cases } \\
\hline & & \multicolumn{2}{|c|}{ Patients with pulmonary TB } & \multicolumn{2}{|c|}{ No suffer pulmonary TB } & \multirow{2}{*}{ p-value } \\
\hline & & $\mathbf{F}$ & $\%$ & $\mathbf{F}$ & $\%$ & \\
\hline 1 & Qualified & 5 & 6,2 & 14 & 17,5 & \\
\hline 2 & Not eligible & & 43,8 & 26 & 32,5 & 0,018 \\
\hline
\end{tabular}

The results of statistical calculations show the $\mathrm{p}$-value $=0.018$ where $\alpha=0.05$ so that the p-value $<\alpha$ which means there is a relationship between home lighting and the incidence of pulmonary tuberculosis. In theory and several studies, suggests that lighting can have a role in the transmission of pulmonary TB because TB germs can last a long time in a room, one of which depends on the availability of natural lighting containing ultraviolet.

In a humid and darkroom, germs can last for days or even months. Dead when exposed to sunlight, soap, Lysol, carbolic and fire heat, mycobacterium tuberculosis bacteria will die within 2 hours by sunlight; by iodic tincture for 5 minutes and also by $80 \%$ ethanol within $2-10$ minutes and dead by $5 \%$ phenol within 24 hours. Houses that do not enter the sun have a risk of suffering from tuberculosis 3-7 times compared with a house that entered the sun. This is in line with the results of research Kurniasari [8] which states that there is a significant relationship between lighting with the incidence of pulmonary TB. This study is in line with the study of Moha and Wahyuni (2012) which revealed there was a relationship between natural lighting with 11 pulmonary TB events $(p=0.00$ and $p=0.010) 6,20$. There was a significant relationship between natural lighting with the incidence of pulmonary TB related with the nature of TB bacteria that are not resistant to sunlight. Sunlight has the power to kill bacteria in at least 60 lux on condition that it is not blinding.

Respondents with natural lighting who are eligible have better access to sunlight. The lighting can enter through ventilation holes, windows, or doors that are often opened, or can be through glass tiles. Respondents with natural lighting did not qualify due to lack of access to light entering the house due to ventilation holes and windows that were rarely opened. Besides, some of the respondents 'houses were blocked by light residents' houses next to them due to the condition of houses that were attached between one house and another.

The relationship between the levels of lighting with tuberculosis from the results of the study it is known that from 17 houses with $80 \%$ lighting experienced TB, while only $37.5 \%$ of houses with good lighting experienced TB events. This shows that there are still many residents who have in bad lighting it caused the level of education is still low $(70.6 \%$ have educated up to junior high and less). To increase knowledge and understanding of the importance of the broad field of illumination, it is necessary to give education about the importance of the broad field of lighting with TB prevention. From the results of the study on the odds lighting ratio, the risk of 6.667 times is greater for pulmonary TB events than respondents who inhabit homes with a good lighting level. This is in line with the results of research conducted by Musadad, the results of his study showed that there was a significant relationship between direct sunlight and 
the incidence of pulmonary tuberculosis. The relationship between the levels of lighting with tuberculosis from the results of the study it is known that from 17 houses with $80 \%$ lighting experienced TB, while only $37.5 \%$ of houses with good lighting experienced TB events. This shows that there are still many residents who have bad lighting it is caused by the level of education is still low (70.6\% have educated up to junior high and less). To increase knowledge and understanding of the importance of the broad field of illumination, it is necessary to educate about the importance of the broad field of lighting with TB prevention. From the results of the study on the odds lighting ratio, the risk of 6.667 times is greater for pulmonary TB events than respondents who inhabit homes with a good lighting level. This is in line with the results of research conducted by Musadad, the results of his study showed that there was a significant relationship between direct sunlight and the incidence of pulmonary tuberculosis.

A research by Sahadewa [17] shows there is a correlation between lighting level and tuberculosis. Based on the result of research and odds ratio testing, poor lighting will raise risk to people have lung TB up to 6.667 times rather than respondents who live in the houses with sufficient lighting.

This research is different from Atmosukarto's and Soeswati's research that proves that people live in the houses with poor lighting significantly will have more risks up to 3-7 times to have tuberculosis rather than people live in the houses with sufficient lighting. Adnani shows that people live in the houses with poor lighting will have more risk up to 2.5 times more to have lung tuberculosis rather that people live in the houses with sufficient lighting in East Jakarta.

Healthy homes require adequate light, especially natural light in the form of sunlight (UV). Natural lighting is a lighting source that comes from sunlight that is all the way that allows for the entry of natural sunlight, for example through windows or glass tiles. This light is very important because it can kill pathogenic bacteria in the house, for example, TB bacteria. It should be noted that direct sunlight can enter the room, not blocked by other buildings. The entrance of light is related to the condition of the window function. Aside from being a vent, windows are also a light entrance. The entrance of natural light can also be cultivated with glass tiles.

\section{Conclusion}

The results of this study indicate that occupancy solidity, ventilation, and lighting do not have a relationship with the incidence of pulmonary TB. Further research needs to be done in identifying housing environmental risk factors on a broader scale with a larger sample of cases.

\section{References}

[1] Dewi, Fitria Erlin, Suhartono, Adi, Sekundarno Mateus. (2016). Hubungan Faktor Lingkungan Rumah dengan Kejadian TB Paru di Kota Magelang. Jurnal Kesehatan Masyarakat, Vol.4/No.2, April 2016.

[2] Deny Agustian., dkk, Hubungan Kondisi Lingkungan Fisik Rumah dengan Kejadian Tuberkulosis Paru di Wilayah Kerja Puskesmas Perumnas I dan II Kecamatan Pontianak Barat, 2014.

[3] Dinas Kesehatan Provinsi Jawa Tengah. (2015). Profil Kesehatan Provinsi Jawa Tengah Tahun 2014 Semarang: Dinas Kesehatan Provinsi Jawa Tengah 
[4] Fatimah, S. 2008. Faktor Kesehatan Lingkungan Rumah yang Berhubungan dengan Kejadian TB Paru Di Kabupaten Cilacap. [Tesis]. Semarang. Universitas Diponegoro Semarang.

[5] Istiqomah, Mursid Rahardjo, Nurjazuli (2018). Hubungan Proporsi Ventilasi Berdasarkan Volume Ruangan Dan Orientasi Matahari Dengan Tuberkulosis Paru Di Puskesmas Mranggen Ii Kabupaten Demak. Jurnal Kesehatan Masyarakat (e-Journal)

[6] Ji Yeon Lee, M.D Tuberculosis Infection Control in Health-Care Facilities: Environmental Control and Personal Protection. 2016 Tuberculosis and respiratory desease

[7] Kemenkes RI. (2016). Petunjuk teknis manajemen dan tatalaksana TB anak. Jakarta: Kementerian Kesehatan RI.

[8] Kurniasari, R. A. S., Suhartono., Cahyo, K. (2012). Faktor Risiko Kejadian Tuberkulosis Paru di Kecamatan Baturetno Kabupaten Wonogiri. Media Kesehatan Masyarakat Indonesia, 11(2), 198204

[9] Lyzigos, Melissa, Natural Ventilation Reduces High TB Transmission Risk in Traditional Homes in Rural Kwazlu-Natal, South Africa, BMC Journal Infectious Disease, 13: 300, 2013

[10] Muaz, F. (2014). Faktor-Faktor Yang Mempengaruhi Kejadian Tuberkulosis Paru Basil Tahan Asam Positif Di Puskesmas Wilayah Kecamatan Serang Kota Serang Tahun 2014. 12-

[11] Moha, S.R. 2012. Pengaruh Kondisi Fisik Rumah Terhadap Kejadian Penyakit Tuberkulosis Paru Di Desa Pinolosian, Wilayah Kerja Puskesmas Pinolosian Kecamatan Pinolosian Kabupaten Bolaang Mongondow Selatan Tahun 2012. [Tesis Ilmiah]. Gorontalo : Universitas Gorongtalo

[12] Nisgunawan Sidiq, Wahiduddin, Dian Sidik. (2013). Faktor Risiko Lingkungan Terhadap Kejadian Tuberkulosis Paru Di Wilayah Kerja Puskesmas Somba Opu. Jurnal MKMI, Maret 2013, hal 29-35

[13] Notoatmodjo, Soekidjo. 2007. Kesehatan Masyarakat Ilmu dan Seni. Jakarta: Rineka Cipta.

[14] Permatasari, A. (2005). Pemberantasan Penyakit TB Paru dan Strategi DOTS. Bagian Paru. FK USU. Medan.

[15] Riswanto, B. 2010. Analisis Spasial Sebaran Kasus Tuberkulosis Paru Ditinjau dari Faktor Lingkungan Dalam dan Luar Rumah Di Kabupaten Pekalongan. [Tesis]. Semarang. Universitas Diponegoro Semarang.

[16] Sari, K. P., Priyo, Widiyanto, P., Yudha, H. T., Yuniar, I., Purwati, et al. (2014). Analisa Situasi Tuberkulosis (TB) Di Kabupaten Kebumen. 10-22.

[17] Sukma Sahadewa, Eufemia, Edwin, Ni Luh, Shita. (2019). Hubungan Tingkat Pencahayaan, Kelembaban Udara, dan Ventilasi udara dengan Faktor Risiko Kejadian TB Paru BTA Positif di Desa Jatikalang Kecamatan Krian Kabupaten Sidoarjo. Jurnal Ilmiah Kedokteran Wijaya Kusuma 8(2): 118-130, September 2019

[18] World Health Organization. (2015). Global Tuberculosis Report 2015 Geneva: World Health Organization

[19] WHO. (2015). Kesehatan Lingkungan. Kesehatan Lingkungan 